\title{
Relationships between Aphids and Ladybeetles on Alfalfa Stands in Northeastern Spain ${ }^{\dagger}$
}

\author{
Roberto Meseguer ${ }^{1, *}$, Alexandre Levi-Mourao ${ }^{1}$ and Xavier Pons ${ }^{1}$ \\ 1 Department of Crop and Forest Sciences, University of Lleida - Agrotecnio-cerca centre, Av. Alcalde Rovira \\ Roure 191, 25198 Lleida, Spain. \\ * Correspondence: roberto.meseguer@udl.cat \\ + Presented at the 1st International Electronic Conference on Entomology (IECE 2021), 1-15 July 2021; \\ Available online: https://iece.sciforum.net/.
}

\footnotetext{
Citation: Meseguer, B.; Levi-

Mourao, A.; Pons, X. Relationships between Aphids and Ladybeetles on Alfalfa Stands in Northeastern Spain, in Proceedings of the 1st International Electronic Conference on Entomology, 1-15 July 2021, MDPI: Basel, Switzerland, doi:10.3390/IECE-10503
}

Published: 1 July 2021

Publisher's Note: MDPI stays neutral with regard to jurisdictional claims in published maps and institutional affiliations.

Copyright: (C) 2021 by the authors. Submitted for possible open access publication under the terms and conditions of the Creative Commons Attribution (CC BY) license (http://creativecommons.org/licenses/by/4.0/).

\begin{abstract}
Aphids are one of the main pests of alfalfa in Spain. The relationship between aphids and ladybeetles has been determined. Alfalfa was sampled by sweep-netting along its productive period in several commercial stands each year between 2010-2020. Acyrthosiphum pisum and Therioaphis trifolii were the most abundant aphid species, peaking in the $2^{\text {nd }}$ and $4^{\text {th }}$ intercut, respectively. Coccinella septempunctata and Hippodamia variegata were by far the coccinelid prevalent species. There were positive correlations between the abundance of $C$. septempunctata and A. pisum at the $2^{\text {nd }}$ intercut; $H$. variegata and T. trifolii at the $4^{\text {th }}$ intercut; and $H$. variegata and the total number of aphids in the $5^{\text {th }}$ intercut.
\end{abstract}

Keywords: Acyrthosiphum pisum; Therioaphis trifolii; Aphis craccivora; Coccinella septempunctata; Hippodamia variegata; population dynamics; numerical responses

\section{Introduction}

Alfalfa, Medicago sativa L., is the world's most valuable cultivated forage crop [1]. In Spain, it is a traditional component of crop rotations. Stands usually remain in the field for 3-6 years, being 4 the usual time. It covers more than 250,000 ha, which represents around the $20 \%$ of the alfalfa surface in Europe [2]. Spain is the main European country exporting alfalfa (dehydrated or pellets), especially to the Middle East countries and China [3]. Its management in Spain consists in regular cuttings during its growing season (usually 5 from the end of April to the end of September at intervals of 30-40 days).

Several pests can economically damage the crop: Hypera postica (Col., Curculionidae), Colaspidema barbarum (Col., Chrysomelidae); Holotrichapion pisi (Col., Curculionidae), lepidopteran leaf feeders (several species) and aphids (Hem., Aphididae). Aphids species occurring in Spanish alfalfa stands are Acyrthosiphon pisum (Harris), Aphis craccivora Koch and Therioaphis trifolii (Monell). Their seasonal occurrence, phenology and population dynamics have been previously reported [4-6]. Although the number of insecticide treatments against aphids has been reduced during the last few years, some sprayings are still applied. In order to develop more sustainable aphid control strategies, it is necessary to know which are the natural enemies associated to aphids and their relationships. In this sense, studies on the occurrence and abundance of natural enemies of the alfalfa aphids in northern Catalonia were developed and the relationships between aphids and parasitoids [6,7] and some heteropteran predators [5] were reported.

Relationships between aphids and ladybeetles (Col.; Coccinellidae) were also investigated in Pons et al. [5] reporting that significant numerical relationships only occurred during the growing alfalfa period between the first and the second cutting. The fact that only two growing seasons were considered in the study and data came from a reduced area from northern Catalonia, close to the Pyrenees, could have mediated the results. 
Therefore, more information from a wider crop cultivation area is needed in order to determine the ladybeetle species complex, their numerical relationships with the main alfalfa aphid species and their potential role as control agents.

The aims of the present work were: 1 ) to identify which coccinellid species were present in alfalfa stands; 2) to determine their relative occurrence; 3 ) to analyse the aphidcoccinellid species associations and 4 ) to define numerical relationships between the most abundant coccinellids and the aphid complex species in each of the five growing alfalfa periods between cuttings (intercuts in advance; see [5,7]).

\section{Material and Methods}

The study was conducted along the Ebro Valley region, in the NE of Spain, where 60 $\%$ and $20 \%$ of the Spanish and European alfalfa surface, respectively, is cultivated.

A total of 93 untreated commercial alfalfa stands were sampled within the period 2010 to 2020 in each of the five intercuts of the growing alfalfa period (from March to September). As the study was part of a more extensive project dealing with the integrated pest management of alfalfa in the region, unequal number of fields were sampled in each of those intercuts, and more data were obtained from the first and the second intercut, when the most damaging pests occurs, H. postica and C. barbarum [8].

Each field was divided in four sectors and three samples per sector were collected following the central part of one of the main diagonals and at least $25 \mathrm{~m}$ apart (following [5]). Samples were taken with a $38 \mathrm{~cm}$ diameter sweep net sweeping it from side to side five times in a $180^{\circ}$ arc. Samples were placed in an icebox and transported to the laboratory, where they were frozen and stored until aphid and ladybeetle individuals were counted and identified to species level. For each aphid species, all morphs and instars were considerate as a whole, whereas larvae and adults of ladybeetles were distinguished. One sample per intercut was obtained. The $1^{\text {st }}$ intercut corresponded to the period from the start of the growing season to the $1^{\text {st }}$ cutting, the $2^{\text {nd }}$ intercut to the period from $1^{\text {st }}$ to the $2^{\text {nd }}$ cutting, and so on.

\subsection{Data Analysis}

The total number of ladybeetles of each species (adults, larvae and total) and aphids (all stages together) recorded in each sampling point of one field were averaged and the field was considered as a replication. Because alfalfa cuttings involve a temporary but drastic change to the system, the five intercuts were considered as separate units.

The numerical relationship between ladybeetle and aphid species in each intercut were determined by correlation analysis. Shapiro Wilk test was used to check for normality before and after transforming data as $(\log (x+1))$. As in any case data followed a normal distribution, the Spearman correlation test was used. No correlation analyses were performed for the $3^{\text {rd }}$ intercut, as the aphid abundances were very low.

Statistical analyses were performed by R Core Team (2020).

\section{Results}

\subsection{Ladybeetle Species and Relative Abundance}

Thirteen coccinellid species were recorded: Coccinella septempunctata L., Hippodamia variegata Goeze, Propylea quatuordecempunctata L., Scymnus spp., Coccinula quatuordecimpustulata L., Exochomus nigromaculatus (Goeze), Tytthaspis sedecimpunctata L., Hyperaspis sp., Adalia bipunctata L., Subcoccinella vigintiquattuorpunctata L., Chilochorus bipustulatus L., Psyllobora vigintiduopunctata L. and Stethorus punctillum (Weise). Whereas C. septempunctata, H. variegata, P. quatuordecempunctata, C. quatuordecimpustulata, Scymnus sp, and E. nigromaculatus are aphidophagous predators, Hyperaspis sp. and C. bipustulatus are mainly coccidophagous, but have aphids as a second- 
ary prey, T. sedecimpunctata and P. vigintiduopunctata eat on fungus, especially powdery mildew and S. vigintiquattuorpunctata is herbivorous. Stethorus puntillum is a mite predator.

A total of 7428 ladybeetles were collected along the ten-year study. The most abundant species were $C$. septempunctata and $H$. variegata, both species accounting for more than $90 \%$ of the total every year and more than $95 \%$ in the whole study. Propylea quatuordecimpunctata and Scymnus sp. were also common species. Adults of these four main species were found over the alfalfa growing season, but the presence of $P$. quatuordecimpunctata and Scymnus sp. larvae was very scarce. The occurrence of the other species was only sporadic.

\subsection{Ladybeetle and Aphid Seasonal Occurrence}

Based on the relative abundance of the coccinellid species, we restrict the results to C. septempunctata and $H$. variegata.

There was a seasonal succession between the occurrence of the two most abundant ladybeetle species (Figure 1). Coccinella septempunctata was abundant, mainly during the $1^{\text {st }}$ and $2^{\text {nd }}$ intercut. Later, the density of adults and larvae decreased considerably. On the contrary, $H$. variegata mainly occurred during the $3^{\text {rd }}, 4^{\text {th }}$ and $5^{\text {th }}$ intercut. Number of larvae of this species was low in the $3^{\text {rd }}$ intercut but it increased considerably during the $4^{\text {th }}$ and $5^{\text {th }}$ intercut.

Relatively to the aphid species, the abundance of A. pisum reached its highest values during the $1^{\text {st }}$ and $2^{\text {nd }}$ intercut and coincided quite well with those of $C$. septempunctata. Therioaphis trifolii peaked in the $4^{\text {th }}$ intercut, just when more H. variegata occurred. However, a drastic decrease of its populations was recorded during the $5^{\text {th }}$ intercut.

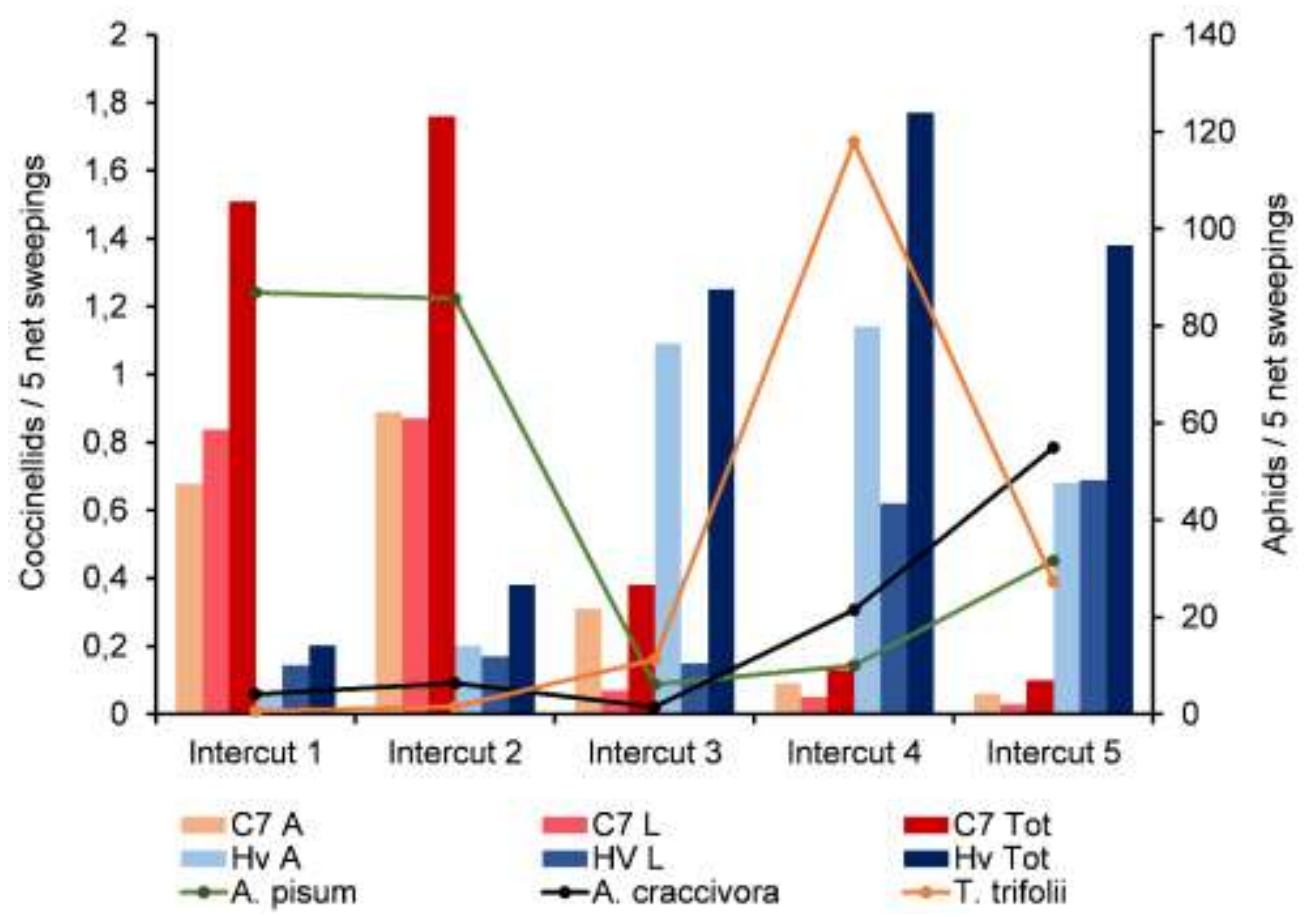

Figure 1. Abundance of the two main ladybeetle species (bars), Coccinella septempunctata (C7) and Hippodamia variegata (Hv) and of the three alfalfa aphid species (lines), Acyrthosiphum pisum, Therioaphis trifolii and Aphis craccivora in each of the 5 intercuts of the growing season. A: adult; L: larvae; Tot: total. 


\subsection{Numerical Relationship between Aphid and Ladybeetle Species}

The numerical relationships between the abundance of ladybeetles and aphids was demonstrated with the correlation analysis in three out of the five intercuts. No significant correlations between C. septempunctata and A. pisum were found in the $1^{\text {st }}$ intercut (Figure $2 \mathrm{a}$, Table A1). Conversely, these two variables were positively correlated during the $2^{\text {nd }}$ intercut (Figure 2b, Table A1). Similarly, positive correlations between H. variegata and $T$. trifolii were found in the $4^{\text {th }}$ intercut (Figure 2c, Table A1). Moreover, in this intercut the abundance of $H$. variegata was also positively correlated with the total number of aphids (which includes $A$. craccivora and A. pisum). Finally, in the $5^{\text {th }}$ intercut, $H$. variegata was positively correlated with $A$. craccivora and again, with the total number of aphids (Figure 2d, Table A1).
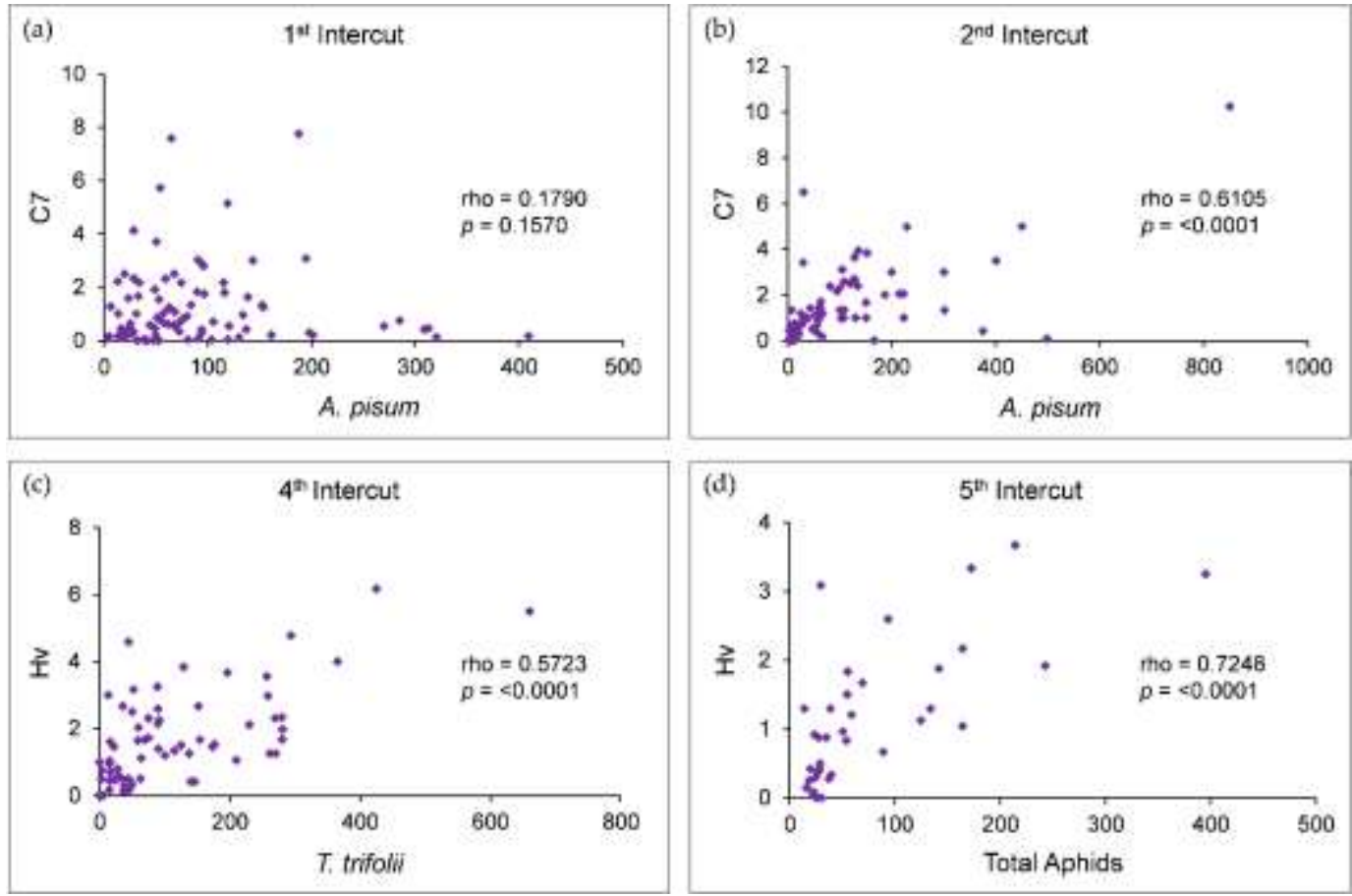

Figure 2. More representative correlation analyses: (a) A.pisum - C. septempunctata (1 ${ }^{\text {st }}$ intercut); (b) A. pisum - C. septempunctata ( $2^{\text {nd }}$ intercut $)$; (c) T. trifolii $-H$. variegata $\left(4^{\text {th }}\right.$ intercut $)$; (d) Total aphids H. variegata (5ำintercut). C7: C. septempunctata; Hv: H. variegata.

\section{Discussion}

Alfalfa is known to be an important reservoir of natural enemies [4,7]. However, studies dealing with the predator/parasitoid-prey relationships of this crop are scarce in Europe. Increasing our knowledge on this area is crucial for the proper management of the agricultural ecosystems. In this ten-year-long study, valuable information of coccinellid-aphid relationships is provided. Thirteen ladybeetle different species were recorded. Within them, C. septempunctata and H. variegata were the prevalent species. This results concur with those of other studies, which also reported these two species as dominant coccinellids on the alfalfa stands in Europe [4,9]. Regarding their seasonal occurrence, our results show a clear transition between both species. Coccinella septempunctata was present on high abundances during the $1^{\text {st }}$ and $2^{\text {nd }}$ intercut, but then, its number considerably decreased in the $3^{\text {rd }}$ intercut, when A.pisum populations declined. Ricci et al. [10] reported that, when aphids are scarce, coccinellid adults leave crops searching for new aphid food, which can be a plausible justification for this drop. This is reinforced by Madeira et al. [11] and di Lascio et al. [12], who observed that, other common crops in the Ebro Valley area, such as maize, can have a "sink" effect during its vegetative growing 
period (coinciding with the alfalfa $3^{\text {rd }}$ intercut) over the alfalfa C. septempunctata populations. Summer diapause has also been described as a common trait of Mediterranean $C$. septempuncata populations [13], so it should also be considered as a possible cause for this decrease. More studies are needed in order to elucidate the phenology of this species in the Ebro Valley area.

Hippodamia variegata highest abundances were shown during the $3^{\text {rd }} 4^{\text {th }}$ and $5^{\text {th }}$ intercut. Its low occurrence during the $1^{\text {st }}$ and $2^{\text {nd }}$ intercut could be related to its better adaptation for reproduction during summer [14,15]. Moreover, the high abundances of C. septempunctata, whose dominance over other coccinellid species has been reported on several studies [16,17], may also have contributed to it. Rondoni et al. [18] recorded intra-guild predation between $C$. septempunctata and $H$. variegata, being asymmetric for the fomer. Such interactions, could have postponed the proper establishment of $H$. variegata in alfalfa until C. septempunctata departure. Although the aphid abundance recorded during the $1^{\text {st }}$ and $2^{\text {nd }}$ intercut was relatively high, intra-guild predation involving coccinellids has been reported as common even at high extraguild prey densities [19].

Results showed positive correlations between C. septempunctata and A. pisum during the $2^{\text {nd }}$ intercut, which concurs with those of Pons et al. [5]. However, no correlations were found during the $1^{\text {st }}$ intercut, when $A$. pisum was equally abundant. Coccinellid aggregative and numerical responses to aphids can be influenced by several factors [20,21], such as the presence of alternative prey [22]. Hypera postica is the main pest attacking alfalfa during this intercut [8] and it has been cited several times as an alternative prey for $C$. septempunctata $[23,24]$. As no significant correlations between $C$. septempunctata and A. pisum were found, and because we had data on the $H$. postica different larval instar abundances for the sampled period, some Spearman correlation tests were run, taking into account this data. We found significant positive correlations between the number of C. septempunctata adults and that obtained after the addition of $A$. pisum and $H$. postica 4 th instar larvae abundances.

The possitive correlations recorded for $H$. variegata in the $4^{\text {th }}$ and $5^{\text {th }}$ intercut partially differ from the results of Pons et al. [5], who only reported a positive correlation between this coccinellid species and $A$. craccivora in the $5^{\text {th }}$ intercut. In our study, the abundant presence of $T$. trifolii during the $4^{\text {th }}$ intercut, may have acted as an attracting and arrestant stimulus for $H$. variegata individuals [25], and thus, led to their possitive correlation. During the $5^{\text {th }}$ intercut, the dominance of $A$. craccivora, which has been already described as a very suitable prey for $H$. variegata [26], may explain its possitive correlation with this aphid species, and thus, with the total number of aphids. The sharp decrease of T. trifolli abundance recorded in this intercut could be due to its own phenology but the predation of $H$. variegata and perhaps other specific natural enemies as parasitoids may also have contributed to it.

Our study provides previously unreported coccinellid-aphid positive correlations, such as $H$. variegata-T. trifolii, besides new information about the coccinellid complex of alfalfa in the Ebro Valley region. More studies are needed in order to increse the knowledge on the predator-prey interactions of this crop in Europe.

Author Contributions: Conceptualization, methodology and validation: R.M. and X.P.; Formal analysis: R.M. and X.P.; Investigation: R.M., A.LM. and X.P.; Resources: X.P.; Data curation: R.M. and X.P.; Writing-original draft preparation: R.M. and X.P.; Writing-review and editing: R.M., A.LM. and X.P.; Supervision: X.P.; Funding acquisition: X.P. All authors have read and agreed to the published version of the manuscript.

Funding: This study was funded by Ministerio de Ciencia, Innovación y Universidades, Spanish Government. Project AGL2017-84127-R: Arable crop management and landscape interactions for pest control. Alexandre Levi-Mourao was funded by a predoctoral JADE plus grant from the University of Lleida and Roberto Meseguer Rosagro by a predoctoral grant FPI-PRE2018-083602, Ministerio de Ciencia, Innovación y Universidades. 
Institutional Review Board Statement: Not applicable.

Informed Consent Statement: Not applicable.

Data Availability Statement: The data presented in this study are available on request from the corresponding author

Acknowledgments: The authors would like to thank A. García for the support with laboratory and field experiments. We also thank J. Piqué, Oses-Nafosa, Aldhara-Europe S.R.L and cooperatives Pirenaica de la Seu d'Urgell, Bell-lloc d'Urgell and Bellvís for allowing sampling in their commercial alfalfa fields.

Conflicts of Interest: The authors declare no conflict of interest. 


\section{Appendix A}

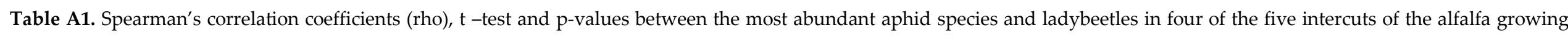
season (the $3^{\text {rd }}$ intercut has not been included due to the low aphid abundance). C7: C. septempunctata; Hv : H. variegata; A = Adults; L = Larvae.

\begin{tabular}{|c|c|c|c|c|c|c|c|c|c|c|c|c|}
\hline & \multicolumn{3}{|c|}{ A. pisum } & \multicolumn{3}{|c|}{ T. trifolii } & \multicolumn{3}{|c|}{ A. craccivora } & \multicolumn{3}{|c|}{ Total aphids } \\
\hline & rho & t-test & p-value & rho & t-test & p-value & rho & t-test & p-value & rho & t-test & $p$-value \\
\hline \multicolumn{13}{|c|}{$1^{\text {st }}$ intercut } \\
\hline C7 A & 0.1889 & 1.51 & 0.1349 & -- & -- & -- & -- & -- & -- & -- & -- & -- \\
\hline C7 L & 0.1667 & 1.33 & 0.1882 & -- & -- & -- & -- & -- & -- & -- & -- & -- \\
\hline $\mathrm{C} 7(\mathrm{~L}+\mathrm{A})$ & 0.1790 & 1.43 & 0.1570 & -- & -- & -- & -- & -- & -- & -- & -- & -- \\
\hline \multicolumn{13}{|c|}{$2^{\text {nd }}$ intercut } \\
\hline C7 A & 0.5648 & 5.56 & $<0.0001$ & -- & -- & -- & -- & -- & -- & -- & -- & -- \\
\hline C7 L & 0.5325 & 5.11 & $<0.0001$ & -- & -- & -- & -- & -- & -- & -- & -- & -- \\
\hline $\mathrm{C} 7(\mathrm{~L}+\mathrm{A})$ & 0.6105 & 6.26 & $<0.0001$ & -- & -- & -- & -- & -- & -- & -- & -- & -- \\
\hline \multicolumn{13}{|c|}{$4^{\text {th }}$ intercut } \\
\hline $\mathrm{Hv}$ A & -0.2031 & -1.65 & 0.1046 & 0.4093 & 3.56 & 0.0007 & -0.366 & -0.29 & 0.7762 & 0.3684 & 3.15 & 0.0025 \\
\hline $\mathrm{Hv} \mathrm{L}$ & 0.5260 & 4.91 & $<0.0001$ & 0.4654 & 4.17 & $<0.0001$ & 0.6036 & 6.01 & $<0.0001$ & 0.4858 & 4.41 & $<0.0001$ \\
\hline $\begin{array}{c}\mathrm{Hv} \\
(\mathrm{L}+\mathrm{A})\end{array}$ & 0.1004 & 0.80 & 0.4263 & 0.5723 & 5.54 & $<0.0001$ & 0,3745 & 3.21 & 0.0021 & 0.5901 & 5.80 & $<0.0001$ \\
\hline \multicolumn{13}{|c|}{$5^{\text {th }}$ intercut } \\
\hline $\mathrm{Hv} \mathrm{A}$ & 0.3395 & 2.10 & 0.0427 & 0.3818 & 2.41 & 0.0216 & 0.4780 & 3.09 & 0.0040 & 0.5541 & 3.88 & 0.0004 \\
\hline $\mathrm{Hv} \mathrm{L}$ & 0.4398 & 2.86 & 0.0073 & 0.0111 & 0.07 & 0.9460 & 0.6518 & 5.15 & $<0.0001$ & 0.6310 & 4.74 & $<0.0001$ \\
\hline $\begin{array}{c}\mathrm{Hv} \\
(\mathrm{L}+\mathrm{A})\end{array}$ & 0.4433 & 2.88 & 0.0068 & 0.1900 & 1.13 & 0.2671 & 0.7298 & 6.22 & $<0.0001$ & 0.7248 & 6.13 & $<0.0001$ \\
\hline
\end{tabular}




\section{References}

1. Orloff, S.B. Introduction. In Intermountain alfalfa management.; Orloff, S., Carlson, H., L.R, T., Eds.; University of California. Division of Agriculture and National Resources: Oakland, 1997; pp. 2-3.

2. Delgado, I.; Lloveras, J. Historia y distribución de la alfalfa. In La alfalfa: agronomía y utilización.; Lloveras, J., Delgado, I., Chocarro, C., Eds.; Edicions de la Universitat de Lleida: Lleida, Spain, 2020; pp. 17-32.

3. Capistrós, J. Comercialización. In La alfalfa: Agronomía y utilización; Lloveras, J., Delgado, I., Chocarro, C., Eds.; Edicions de la Universitat de Lleida: Lleida, Spain, 2020; pp. 343-364.

4. Pons, X.; Núñez, E.; Lumbierres, B.; Albajes, R. Epigeal aphidophagous predators and the role of alfalfa as a reservoir of aphid predators for arable crops. Eur. J. Entomol. 2005, 102, 519-525, doi:10.14411/eje.2005.074.

5. Pons, X.; Lumbierres, B.; Albajes, R. Heteropterans as aphid predators in inter-mountain alfalfa. Eur. J. Entomol. 2009, 106, 369-378, doi:10.14411/eje.2009.047.

6. Pons, X.; Lumbierres, B.; Comas, J.; Madeira, F.; Starý, P. Effects of surrounding landscape on parasitism of alfalfa aphids in an IPM crop system in northern Catalonia. BioControl 2013, 58, 733-744, doi:10.1007/s10526-013-9534-y.

7. Pons, X.; Lumbierres, B.; Antoni, R.; Starý, P. Parasitoid complex of alfalfa aphids in an IPM intensive crop system in northern Catalonia. J. Pest Sci. (2004). 2011, 84, 437-445, doi:10.1007/s10340-011-0383-0.

8. Pons, X.; Núñez, E. Plagas de la alfalfa: Importancia, daños y estrategias de control. In La alfalfa: Agronomía y utilización; Lloveras, J., Delgado, I., Chocarro, C., Eds.; Edicions de la Universitat de Lleida: Lleida, Spain, 2020; pp. 167-202.

9. Jovičić, I.; Radonjić, A.; Petrović-Obradović, O. Aphids (Hemiptera: Aphididae) on alfalfa and and their coccinellid predators in Serbia: Seasonal abundance. Acta Zool. Bulg. 2016, 68, 581-587.

10. Ricci, C.; Ponti, L.; Pires, A. Migratory flight and pre-diapause feeding of Coccinella septempunctata (Coleoptera) adults in agricultural and mountain ecosystems of Central Italy. Eur. J. Entomol. 2005, 102, 531-538, doi:10.14411/eje.2005.076.

11. Madeira, F.; di Lascio, A.; Carlino, P.; Costantini, M.L.; Rossi, L.; Pons, X. Stable carbon and nitrogen isotope signatures to determine predator dispersal between alfalfa and maize. Biol. Control 2014, 77, 66-75, doi:10.1016/j.biocontrol.2014.06.009.

12. di Lascio, A.; Madeira, F.; Costantini, M.L.; Rossi, L.; Pons, X. Movement of three aphidophagous ladybird species between alfalfa and maize revealed by carbon and nitrogen stable isotope analysis. BioControl 2016, 61, 35-46, doi:10.1007/s10526-0159697-9.

13. Katsoyannos, P.; Kontodimas, D.C.; Stathas, G.J. Summer diapause and winter quiescence of Coccinella septempunctata (Col. Coccinellidae) in Central Greece. 1997, 42, 483-491, doi:10.1007/BF02769808.

14. Iperti, G. The choice of oviposition sites in aphidophagous Coccinellidae. In Ecology of Aphidophagous Insects; Hodek, I., Ed.; Academia: Prague, Czech Republic, 1966; pp. 121-122.

15. Mandour, N.S.; Sarhan, A.A.; El-Basha, N.A.; Abdel-Motaal, D.S. Effect of different temperature regimes on the biology, reproduction and predation of Hippodamia variegata (Goeze) (Coleoptera: Coccinellidae). Egypt. J. Biol. Pest Control 2011, 21, 305-312.

16. Obrycki, J.J.; Kring, T.J. Predaceous coccinellidae in biological control. Annu. Rev. Entomol. 1998, 43, 295-321, doi:10.1146/annurev.ento.43.1.295.

17. Snyder, W.E.; Clevenger, G.M.; Eigenbrode, S.D. Intraguild predation and successful invasion by introduced ladybird beetles. Oecologia 2004, 140, 559-565, doi:10.1007/s00442-004-1612-5.

18. Rondoni, G.; Ielo, F.; Ricci, C.; Conti, E. Intraguild predation responses in two aphidophagous coccinellids identify differences among juvenile stages and aphid densities. Insects 2014, 5, 974-983, doi:10.3390/insects5040974.

19. Gardiner, M.M.; Landis, D.A. Impact of intraguild predation by adult Harmonia axyridis (Coleoptera: Coccinellidae) on Aphis glycines (Hemiptera: Aphididae) biological control in cage studies. Biol. Control 2007, 40, 386-395, doi:10.1016/j.biocontrol.2006.11.005.

20. Hemptinne, J.L.; Dixon, A.F.G.; Coffin, J. Attack strategy of ladybird beetles (Coccinellidae): factors shaping their numerical response. Oecologia 1992, 90, 238-245, doi:10.1007/BF00317181.

21. Tulli, M.C.; Carmona, D.M.; Vincini, A.M. Influence of plant diversity on the numerical response of Eriopis connexa (Coleoptera: Coccinellidae) to changes in cereal aphid density in wheat crops. Int. J. Ecol. 2013, 2013, doi:10.1155/2013/789532.

Evans, E.W.; Toler, T.R. Aggregation of polyphagous predators in response to multiple prey: ladybirds (Coleoptera: Coccinellidae) foraging in alfalfa. Popul. Ecol. 2007, 49, 29-36, doi:10.1007/s10144-006-0022-4.

23. Kalaskar, A.; Evans, E.W. Larval responses of aphidophagous lady beetles (Coleoptera: Coccinellidae) to weevill larvae versus aphids as prey. Ann. Entomol. Soc. Am. 2001, 94, 76-81, doi:10.1603/0013-8746(2001)094[0076:LROALB]2.0.CO;2.

24. Richards, D.R.; Evans, E.W. Reproductive responses of aphidophagous lady beetles (Coleoptera: Coccinellidae) to nonaphid diets: an example from alfalfa. Ann. Entomol. Soc. Am. 1998, 91, 632-640, doi:10.1093/aesa/91.5.632.

25. Honek, A. Distribution and habitats. In Ecology and behaviour of the ladybird beetles (Coccinellidae); Hodek, I., Van Emden, H., Honek, A., Eds.; Blackwell: Chichester, UK, 2012; pp. 110-140.

26. Pervez, A.; de Holanda Nunes Maia, A.; Bozdoğan, H. Reproduction and demography of an aphidophagous ladybird, Hippodamia variegata on six aphid species. Int. J. Trop. Insect Sci. 2020, 541-548, doi:10.1007/s42690-020-00101-2. 